\title{
MARKET CONDITIONS IN THE HEALTH SYSTEM
}

\author{
L. Tuaeva \\ Financial University under the Government of the Russian Federation \\ Vladikavkaz, Russian Federation
}

Zh. Kochieva

\author{
South Ossetian Research Institute. Tskhinvali, Republic of South Ossetia \\ science-almanac@mail.ru
}

\begin{abstract}
The initial position of the study, the results of which are presented in the article, is the statement that health as a specific social sphere of society has its own peculiarities, presupposing the primacy of medical results over financial ones. And in this sense, market relations action sphere of in health service is limited. The concept, explaining the need for civil service or public health control is concluded in the fact that the free market (in its pure form), often considered to be a self-regulating and most effective way of achieving the enterprise rise, is simply unsuitable for the health service system due to the fact that health service, as a branch of the social economy, has a number of characteristics that violating the market operation mechanism.

The development of market relations, at the moment, practically has not affected the authorities financial mechanism, where the extensive approach under financing still prevails. In modern conditions, domestic health service financing requires a thorough rethinking. Health service as a branch of the public economy has a number of characteristics, violating the market mechanism operation. There is an acute problem of used resources efficient allocation to improve the accessibility and quality of medical assistance. Its solution requires improving management practices, comparative evaluation methods of possible variants available resources distribution and choice grounding of the best of them, which is connected with economic, market, technological, social, political and other factors that need to be addressed.
\end{abstract}

Key words: health service, market, market relations, financial mechanism, free market.

The state as an institutional system endowed with universally recognized authority and responsible for the development of the social sphere, forms a health institute. This institute organizes social connections of threeeconomic-juridical institutes - state, enterprises and home economics. Public benefits are formed, distributed and consumedin the process of health institute functioning. Taking rational actions of people for the basic institutional norms during their life cycle, it can be considered that the institution of public health is manifested in the forms of institutions of budgetary financing, compulsory and voluntary personal insurance and tax incentives. Health service is realized by appropriation of funds to all home economics from state (municipal) sources, from the enterprises own means (compulsory health insurance), from citizens' savings (voluntary health insurance), and also through decrease of home economics tax liabilities (taxpreference) [1].

Study of mechanisms, operating the branch is considered to be the important condition for health service functioning peculiarities understanding. Evidently that health service acquires and permits its dynamics, basing on modern demands in health as society in whole, so its components, including household and medical and preventive treatment facilities (MPTF). In this regard, the positioning of the category"need" as the main guideline for the development of healthcare system technologies presumably will allow the discovery of new sectoral activities tools, especially those that are required under the limited resources, directed at improving health care. Health service fiscal system - is a form of financial relations organization at the federal level, at the level of federation subjects and at the local 
level, being in communication with each other and forming certain integrity, the direction unity for the citizens health protection.

Health systems have to adapt to the constantly alterative and often competing needs for financial resources. In order the system functions at the proper level, it should have sufficient funds to invest in buildings and equipment, cover the costs of training staff, and pay staff, purchase medicines and other expendable materials.

Health service branch of modern Russia is considered to be specific from financial positions, as monetary funds, coming from the accounting system, and assets of enterprise, organizations, individuals through the system of compulsory health insurance $(\mathrm{CHI})$, and own means, obtained by the health care facilities from paid service rendering for population and legal bodies act the financial resources formation source and its expenditures financing.

With the transition of Russian health care to market relations, certain changes took place in the character of financial relations implementation between healthcare subjectsand, accordingly, the financial mechanism, namely:

- alteration of financial flows to health service - along with remaining financing from the budget, the sphere of health service financing is directly developed by the taxpayers: as through deductions tocompulsory health insurance, so by means of voluntary health insurance (VHI) and direct payment of medical assistance,

- increase in the number of bodies, involved in the health service financing: the funds of compulsory medical insurance, insurance organizations, charitable and public funds, etc. appear in addition to state financial bodies;

- alteration of financial payments principle - not expenditures financing, but partial purchase of medical institutions services bypayers;

- alteration of the state role in financial health service system - it begins to act as not the guarantee of common free medical care, but as one of the medical assistance customers for the separate population categories;

- increase of regional, local budgets role and decrease of federal budget role;

- volume increase of paid services, rendered by state (municipal) MPTF;

- formation of commercial health serve sector.

Thus, the mechanism of medical institutions management and, first of all, the mechanism of financial resources formation are changed. Its elements are undergone to the fundamental reconstruction, aimed to fuller satisfaction of citizens needs in the qualified medical assistance.

The transition is realized, where it is possible, from financing of medical institutions to financing of medical assistance rendering that is achieved through transition to insurance financing form. The payment volumetric method of medical assistance is used, which presupposes that if the system works effectively and sufficient number of works and services is realized in its frames, then it will provide the necessary volume of realization and, accordingly, necessary volume of medical institution financing. Thus, the problems, appearing under the estimated financing method are solved, but, unfortunately, this method can stimulate the growth of gross performance, often in the prejudice of qualitativeindice.The main difference of medical insurance from the state (budget) health system is: the money is paid only after insurance case occurrence -citizen resorting to a doctor. Financing principles cardinally alter: deviation from money appropriation to medical institution in any case and transition to financing per capita. The new financial system for health service is realized, when financial assets from the insurance payers come to MPTF according the principle - "money comes for the patient", under which the gathered facilities by local funds stay in the territories. 
It should be mentioned that health service as specific social sphere has its peculiarities, presuppose the priority of medical results over financial one. And in this sense, the scope of market relations in health service is limited.

The conception, explaining, the necessity ofcivil service and health service state control, is concluded in the fact that free market (in pure form) often considered to be selfregulating and mainly effective method of branch rise achievement, is practically improper for health service system, considering that health service, as a the branch of social economy, possesses a row of characteristics, violating the activity of market mechanism.

The most important of them are considered in the following:

1. The customers presence, having the full information, considering price, volume and quality of acquired goods and determining demand, and also salesman, determining the offer is necessary for existence of free market.However, in medicine the customerpatient does not determine demand to the concrete service, but onlypartly to the health system services, in general. The doctor, determining simultaneously demand and supply, appears to be in the most advantageous position, obtaining the absolute power to sale something that is profitable first of all for him in the conditions of free market. The reason of so called "demand, generated by the offer" lies in the original information asymmetry: as only the doctor, endowed with knowledge, permitting to decide about patient's treatment, and the patient does not possess the knowledge, which would allow him to estimate the volume of provided services.

2. Some types of health care services benefit to society than an individual (possess peculiarities of "social goods"). The classical example of service to prevent infection diseases is considered to be vaccination. That is why resources distribution on the basis of only solvent demand and entrepreneurial motives does not provide satisfaction of social demand. In other words medical services turn to be too useful for society in whole, and consequences, which they prevent (epidemic) are too serious, to leave them to the discretion of every citizen.

3. Violation of access equality principles to minimal set of mainly important health service system, especially in case of life threat, is unacceptable for the majority of developed countries citizens. This is especially evident in those cases, when extreme medical assistance is required forsufferings decrease and life saving[2].

4. Free entrance of the salesman and customer is a necessary condition for free market existence. Unlimited admission of medical services salesman would undoubtedly harm the health and well-being of the nation.

Based on the abovementioned information, it can be concluded that the free market is unsuitable for regulating the health system. Impropriety of free market does not denote that its separate elements cannot be used in health systems, regulated by state, for creation of competition between salesman, using resources efficiency increase, doctors motivation and consumers stimulation[3]. And so as double nature of health care services conditions necessity of social and private sectors existence in health service under the conditions of market economy, then financial mechanism, consequently, should combine principles of state and market regulation. That is why the problem is concluded in a part determination of some or other regulation type, in finding optimal correlation between state and market in health service system financing.

Thus, under the organization of financial health service mechanism, one should consider the following:

- rationally organized financial mechanism, which corresponds to the modern level of developed, civilized countries is capable to be driving force of health service development;

- every element of financial mechanism performs its function, however, their actions should be interrelated, coordinated and work to the main challenge - financial resources accumulation of medical institutions, regulation and control over their expenses; 
- health services financial mechanism in the result of their entrance into market environment significantly changes;

- todays existing budget financial mechanism in Russia is capable only to reproduce the current regime of institutions economy and it is also incompatible with requirements of effective resources using [4]. Extravagant financing order under the absence of resulting indice order and generalinsufficiency of appropriate resources creates the situation under which thequestion formulation about efficiencycorrect estimation of budgetary provisions using is considered to be problematic[5];

- financing system of MPTF from the budget and medical assistance payment system from $\mathrm{CHI}$ facilities act according to the different rules, which are incorrectly coordinated with each other. Thus, the existing organization of state medical institutions financing does not create motivations, inducing them to promotion of their activity efficiency.

\section{Лumepamypa}

1. Концепция развития системы здравоохранения в РФ до 2020 года. http://www.zdravo2020.ru/concept/Konzeptciya_Zdravo2020/doc

2. Туаева Л.А. Взаимосвязь между медико-демографической ситуацией и социально-экономическим положением в Республике Северная ОсетияАлания//TerraEconomicus. 2013. T. 11. № 3-3.

3. Tadtaeva V.V., Tuaeva L.A. Health economics: problems and prospects//Наукаитехнологии. 2013. Т. 1. № 3.

4. Туаева Л.А., Сугарова И.В. Эфрфективность расходования средств на систему здравоохранения// TerraEconomicus. 2013. Т. 11. № 3-3.

5. Shkurkin D.V., Shestopal S.S., Gurieva L.K., Blaginin V.A., Gurianov P.A. Basic characteristics of an intensive type of the reproduction process in the regional economy//International Review of Management and Marketing. 2016. T. 6. № S1.

\section{References}

1. Health service system development conception in RF till 2020. http://www.zdravo2020.ru/concept/Konzeptciya_Zdravo2020/doc

2. Tuaeva L.A.interconnection between medical-demographical and socioeconomic situation in Republic of North Ossetia-Alaniya//Terra Economicus. 2013. Vol. 11. No 3-3.

3. Tadtaeva V.V., Tuaeva L.A. Health economics: problems and prospects//Science and technologies. 2013. Vol. 1. No 3.

4. Tuaeva L.A., Sugaroval.V.Facilities expenditure efficiency to the system of health service system // Terra Economicus. 2013. Vol. 11. No 3-3.

5. Shkurkin D.V., Shestopal S.S., Gurieva L.K., Blaginin V.A., Gurianov P.A. Basic characteristics of an intensive type of the reproduction process in the regional economy//International Review of Management and Marketing. 2016. Vol. 6. No S1. 